\title{
The consensus development programme: technology assessment at the National Institute of Health
}

\author{
CHARLES U LOWE
}

Are there some medical technologies in general use that are unsafe or ineffective? Are there still other drugs, devices, and medical or surgical procedures that have not been widely accepted even though well validated? These are the kinds of questions, raised in recent years, that have led to a reassessment of the process by which technologies are transferred from research and development into practice.

During the past 30 years major advancements have been made in medical care, and with these improvements has come a rapid expansion of the role of science and technology in medicine. In the United States, however, there was no formal mechanism within the biomedical research community to ensure that findings were systematically identified and evaluated to determine whether they were suitable for introduction into practice.

\section{Consensus conferences}

Amid a growing public concern about the lack of a more organised system of assessing medical technologies, the National Institutes of Health in 1977 initiated its Consensus Development Programme. The purpose was to help improve the translation of the results of biomedical research into knowledge that could be used effectively in the practice of medicine and public health.

A key element in the programme is the consensus conference, which brings together scientists, practitioners, consumers, and others in an effort to reach general agreement on the safety and efficacy of medical technologies. The technologies may be

Office for Medical Applications of Research, National Institutes of Health, Bethesda, Maryland 20205, USA

CHARLES U LOWE, MD, acting associate director emerging or may be in general use. They may be drugs, devices, or medical, surgical, or dental procedures.

The Consensus Development Programme is aimed at complementing - but not replacing-the usual means of reporting research results through publication in scientific journals and other medical periodicals and through the lay press. The primary objective of the programme is to provide the physician and the public with the most accurate, current information about the benefits and risks of complex, often controversial, medical technologies.

Consensus development conferences differ from standard scientific state-of-the-art meetings in that consensus panels must consider specific sets of questions. After listening to a series of expert presentations, these panels are then asked to issue a set of recommendations framed around the original questions and directed to the technology under discussion.

The value of the reports prepared by consensus panel members is that they may identify safe and useful new medical technologies and make a wider audience aware of their availability. On other occasions they may point out some potential problems which could result from the use of an existing technology. In some cases panels may even recommend against using a medical or surgical procedure, device, or drug under certain conditions. Sometimes the consensus indicates that a technology has not been adequately validated.

\section{The best current thinking}

Whatever the conclusions drawn by a panel, the group's report is offered as an aid to the physician and the public. The hope is that the more current, reliable scientific information reaches the medical profession and the public the more the quality of health care will improve. 
NIH Consensus conferences and their sponsors

\begin{tabular}{|c|c|c|c|}
\hline Sponsors & 1978 Conferences & 1979 Conferences & 1980 Conferences held or planned \\
\hline National Cancer Institute & $\begin{array}{l}\text { Educational needs for physicians and } \\
\text { public regarding asbestos exposure } \\
\text { Mass screening for colorectal cancer } \\
\text { Mass screening for lung cancer }\end{array}$ & $\begin{array}{l}\text { Health education priorities for cancer } \\
\text { control } \\
\text { Primary breast cancer: management of } \\
\text { local disease } \\
\text { Steroid receptors in breast cancer }\end{array}$ & $\begin{array}{l}\text { Adjuvant chemotherapy for breast cancer- } \\
\text { 14-16 July } \\
\text { Cervical cancer screening: Pap smear } \\
\text { (co-sponsored by NCI, NIA and } \\
\text { NICHD in conjunction with NCHCT)- } \\
23-25 \text { July } \\
\text { CEA and immunodiagnosis-29 September- } \\
1 \text { October } \\
\text { CT scanning of CNS (co-sponsored by } \\
\text { NINCDS and NCI, in conjunction with } \\
\text { NCHCT)-27-29 October }\end{array}$ \\
\hline \multirow[t]{2}{*}{$\begin{array}{l}\text { National Heart, Lung, and } \\
\text { Blood Institute }\end{array}$} & & $\begin{array}{l}\text { Transfusion therapy in pregnant sickle } \\
\text { cell disease patients } \\
\text { Improving clinical and consumer blood } \\
\text { pressure measuring devices }\end{array}$ & $\begin{array}{l}\text { Fibrinolytic therapy for thrombosis- } \\
10-12 \text { April } \\
\text { Coronary bypass surgery-3-5 December }\end{array}$ \\
\hline & & & $\begin{array}{l}\text { Continuing activities } \\
\text { Black Health Providers Task Force on } \\
\text { high blood pressure education and } \\
\text { control-to be determined } \\
\text { Joint National Committee on Detection, } \\
\text { Evaluation, and Treatment of High } \\
\text { Blood Pressure- to be determined }\end{array}$ \\
\hline $\begin{array}{l}\text { National Institute of Allergy } \\
\text { and Infectious Diseases }\end{array}$ & $\begin{array}{l}\text { Availability of insect sting kits to } \\
\text { non-physicians }\end{array}$ & $\begin{array}{l}\text { Amantadine in the prevention and } \\
\text { treatment of influenza }\end{array}$ & \\
\hline $\begin{array}{l}\text { National Institute of Arthritis, } \\
\text { Metabolism and Digestive } \\
\text { Diseases }\end{array}$ & Surgical treatment of morbid obesity & & $\begin{array}{l}\text { Endoscopy in upper gastrointestinal } \\
\text { haemorrhage }-20-22 \text { August }\end{array}$ \\
\hline $\begin{array}{l}\text { National Institute of Child } \\
\text { Health and Human } \\
\text { Development }\end{array}$ & & Antenatal diagnosis & $\begin{array}{l}\text { Childbirth by caesarean delivery-22-23 } \\
\text { September }\end{array}$ \\
\hline National Institute on Aging & Treatable brain diseases in the elderly & Ostrogen use and postmenopausal women & \\
\hline $\begin{array}{l}\text { National Institute of Dental } \\
\text { Research }\end{array}$ & Dental implants benefit and risk & $\begin{array}{l}\text { Consensus development for removal of } \\
\text { third molars }\end{array}$ & $\begin{array}{l}\text { Therapeutic methods for treating } \\
\text { periodontal disease- to be determined }\end{array}$ \\
\hline $\begin{array}{l}\text { National Institute of General } \\
\text { Medical Sciences }\end{array}$ & Supportive therapy in burn care & & $\begin{array}{l}\text { Liposomes as carriers for drugs-to be } \\
\text { determined }\end{array}$ \\
\hline $\begin{array}{l}\text { National Institute of } \\
\text { Neurological and } \\
\text { Communicative Disorders } \\
\text { and Stroke }\end{array}$ & $\begin{array}{l}\text { Indications for tonsillectomy and } \\
\text { adenoidectomy-phase I }\end{array}$ & & $\begin{array}{l}\text { Long-term management of children with } \\
\text { febrile seizures -19-21 May } \\
\text { CT scanning of CNS (co-sponsored by } \\
\text { NINCDS and NCI in conjunction with } \\
\text { NCHCT)-27-29 October }\end{array}$ \\
\hline National Eye Institute & & Intraocular lens implantation & \\
\hline Division of Research Services & & $\begin{array}{l}\text { The use of microprocessor-based, } \\
\text { "intelligent" machines in patient care }\end{array}$ & \\
\hline $\begin{array}{l}\text { Interagency Committee on New } \\
\text { Therapies for Pain and } \\
\text { Discomfort }\end{array}$ & & Pain, discomfort, and humanitarian care & \\
\hline
\end{tabular}

Consensus summary reports are not regulations. They simply represent the best current thinking by those in the best position to know. The reports are never considered final. Since medical technology is evolving, what may be true today may change tomorrow. Plans to update consensus reports when appropriate are under way.

Another important feature of consensus development conferences is the inclusion of ample time on the agenda for public comments. Frequently; the consensus report reflects some key points made by knowledgeable members of the audience.

It is desirable that panel lists explore all sides of a question, and panel members who disagree with major conclusions are encouraged to develop a minority report.

The fact that panel members may be unable to reach consensus on a specific point may sometimes be as valuable as when they are in agreement because this could well point to a need to develop more data on the subject in question.

So far the NIH Consensus Development Programme has conducted some two dozen conferences on a wide range of subjects (see table).

\section{The role of NIH}

The Office for Medical Applications of Research (OMAR), located in the Office of the Director at NIH, co-ordinates and facilitates the programme and monitors and evaluates it. In addition to working closely with the NIH institutes, bureaux, and divisions which sponsor consensus development conferences, OMAR provides a vital link between NIH technology assessment activities and the National Centre for Health Care Technology.

While NIH focuses on the technical, scientific aspects of assessments, the centre is concerned with ethical, social, economic, and legal facets. Besides the centre, such health and human services agencies as the Food and Drug Administration and the Centre for Disease Control have also participated in consensus meetings at NIH.

No federal officials are directly involved with the deliberations of the consensus development panel. NIH serves only as the catalyst, providing the resources for the consensus activities.

In the short time that the Consensus Development Programme has been in operation, it has not been possible to evaluate the impact. Plans are under way, however, to survey segments of the medical community in order to assess the effect of this effort.

\section{Filling a gap}

An important element in the process of transferring research information into practice has always been the clinical trial. A properly designed and well-conducted trial can lead to the validation of a new, superior medical intervention. It may also question the effectiveness of a well-established procedure.

As with any research finding, the results of a clinical trial reach the practising community in various ways-at professional meetings, through journals, at seminars, and through continuing education programmes. Although all of these avenues help physicians to keep abreast of current thinking, they do not provide them with the opportunity to assess the degree to which a technology has been tested for safety and effectiveness.

This is where the NIH Consensus Development Programme can play an important role: it supplies the practitioner with critiques of complex medical technologies prepared by a wide range of experts. By helping to fill this knowledge gap the programme is expected to contribute measurably to an improvement in the quality of medical practice.

The BMF proposes to publish future consensus conference reports as they are issued. The first-on thrombolytic treatment-follows this article. 